\title{
Preparation and Characterization of Sugar Based Catalyst on Various Supports
}

\author{
Jidon Adrian Janaun, Tan Jaik Mey, Awang Bono, Duduku Krishnaiah* \\ Catalysis, Reaction Engineering \& Drying Technology Research (CREDYT), Faculty of Engineering, \\ Universiti Malaysia Sabah, 88400 Kota Kinabalu, Sabah, Malaysia
}

Received: 20th April 2016; Revised: 14 ${ }^{\text {th }}$ October 2016; Accepted: 17th October 2016

\begin{abstract}
A novel structured carbon-based acid catalyst was prepared by depositing the carbon precursor onto glass, ceramic and aluminum supports via dip-coating method, followed by carbonization process for converting the $d$-glucose layer into black carbon char in an inert nitrogen environment at $400{ }^{\circ} \mathrm{C}$. Then, the $-\mathrm{SO}_{3} \mathrm{H}$ group was introduced into the framework of the carbon char by multiple vapor phase sulfonation. Four different carbonization methods were carried out (dry pyrolysis and hydrothermal carbonization with or without pressurized) in the catalyst preparation while among the carbonization methods, the samples which prepared from dry pyrolysis without pressurized process showed the strong acidity due to highest adsorption of acid group in the catalyst surface although the catalyst attached onto the support was the least compared to other preparation methods. Among the catalysts, the sulfonated carbon-base catalyst that is attached on the ceramic support exhibited the highest acidity $(1.327 \mathrm{mmol} / \mathrm{g})$ followed by the catalyst deposited on the glass $(0.917 \mathrm{mmol} / \mathrm{g})$ and aluminum $(0.321 \mathrm{mmol} / \mathrm{g})$ supports. The porous structure of ceramic surface, allowed a better interaction between reactants and $-\mathrm{SO}_{3} \mathrm{H}$ site in the carbon. Through the FT-IR analysis, it was observed that the functional groups $-\mathrm{COOH},-\mathrm{OH}$, and $-\mathrm{SO}_{3} \mathrm{H}$ were present in the active sites of the catalysts. The surface areas of glass ( $\mathrm{Si}-\mathrm{SC})$, ceramic $(\mathrm{Ce}-\mathrm{SC})$ and aluminum $(\mathrm{Al}-\mathrm{SC})$ catalysts were larger than $1 \mathrm{~m}^{2} / \mathrm{g}$, whereas the pore size belongs to macroporous as the average pore size is more than $50 \mathrm{~nm}$. It is also stable within the temperature of $400{ }^{\circ} \mathrm{C}$ as there was less than $10 \%$ weight loss revealed from the TGA analysis. Copyright (C) 2017 BCREC GROUP. All rights reserved
\end{abstract}

Keywords: structured sulfonated carbon-base acid catalyst; sugar catalyst; catalyst support; carbonization; multiple phase vapor sulfonation

How to Cite: Janaun, J.A., Mey, T.J., Bono, A., Krishnaiah, D. (2017). Preparation and Characterization of Sugar Based Catalyst on Various Supports. Bulletin of Chemical Reaction Engineering \& Catalysis, 12 (1): 41-48 (doi:10.9767/bcrec.12.1.478.41-48)

Permalink/DOI: http://dx.doi.org/10.9767/bcrec.12.1.478.41-48

\section{Introduction}

Fossil fuels are currently crucial sources of primary energy supplied throughout the world and play an essential role in economic growth of the developing countries. However, due to increasing energy demand, it was estimated that the global reserves of fossil fuels will last for

* Corresponding Author.

E-mail: krishna@ums.edu.my

Telp.: +60-88-320000 Fax.: +60-88-320348 another 40 to 60 years [1]. Moreover, the widespread use of fossil fuels cause escalating price of crude oil in the world market. Several adverse environmental impacts such as greenhouse effect, global warming, as well as climate change due to large emission of greenhouse gases (GHSs) and others hazardous pollutants are raising the public concern towards the alternative sources for petroleum based fuels [2]. Fatty acid methyl ester (FAME) is an alterna- 
tive promising biodiesel fuel that is derived from the renewable biomass such as vegetable oils, animal fats, waste oils and waste greases [3]. Generally, biodiesel can be produced from esterification of fatty acids (FAA) or through the transesterification reaction of triglycerides with a short-chain alcohol in the presence of homogeneous or heterogeneous alkali-, acid- or enzyme catalyst [4].

Among the catalytic processes, heterogeneous acid catalyzed process has been more widely favored compared to other catalytic processes as it can be easily separated form reaction mixture through decantation or filtration, and making the purification step much simpler with minimum energy consumption and easy to recover without waste. Thus it is more environmental friendly and more economically competitive due to the lowest total capital investment and manufacturing cost among the catalytic processes. Although the reaction of alkali catalyzed process is faster than acid catalyzed process, the alkali catalyzed process is not suitable for low-quality feedstock which contains high level of free fatty acid (FFA) and water content as soap is formed during the transesterification process. Whereas, the solid acid catalyst is ideal for the lowquality feedstock because the catalytic reaction is less affected by the presence of water and free fatty acid (FFA) [3]. Among the solid acid catalysts such as tungstated zirconia-alumina (WZA), sulfated zirconia-alumina (SZA), sulfated tin oxide (STO), and amberlyst-15 (sulfonated polystyrene-based resin), the carbon-based solid acid catalyst bearing with $-\mathrm{SO}_{3} \mathrm{H},-\mathrm{COOH}$ and phenolic $-\mathrm{OH}$ groups exhibit remarkable catalytic performance in both esterification and transesterification processes as it is highly active and requires relatively low temperature than other typical solid acid catalyst [4]. Besides, this carbon-based catalyst is inexpensive, stable and renewable catalyst as an environmentally benign replacement for $\mathrm{H}_{2} \mathrm{SO}_{4}[3,4]$.

Sugar catalyst is also known as carbonbased solid acid catalyst, derived from the incomplete carbonization of simple sugar followed by sulfonating the pyrolized sugar with concentrated $\mathrm{H}_{2} \mathrm{SO}_{4}$. These types of catalysts were reported to show excellent catalytic performance in biodiesel synthesis especially for low quality feedstock due to the presence of polycyclic aromatic hydrocarbon containing $-\mathrm{SO}_{3} \mathrm{H}$ groups and phenolic $-\mathrm{OH}$ and $-\mathrm{COOH}$ groups [5]. The high density of functional group of $-\mathrm{SO}_{3} \mathrm{H}$ and bending mode of $-\mathrm{OH}$...... $\mathrm{O}=$ linked by a strong hydrogen bond, this catalyst is comparable to the strong liquid Brönsted acid catalyst despite low surface area $\left(2.5 \mathrm{mmolg}^{-1}\right.$ total and 1.2 mmolg- ${ }^{-1}-\mathrm{SO}_{3} \mathrm{H}$ density). Due to the $-\mathrm{SO}_{3} \mathrm{H}$ groups in the catalyst linked by strong hydrogen bonds, strong acidity can result by mutual electron-withdrawal. Besides, the bending mode of $-\mathrm{OH} . . . . . \mathrm{O}=$ linked by a strong hydrogen bond, enables the catalyst to incorporate a large amount of hydrophilic molecules, including water into the vacancies among the domains of catalyst. It enhances their accessibility to Brönsted acid sites in the carbon material, resulting higher catalytic activity than other solid acid catalysts $[4,6]$. However, due to the fine powder form of sugar catalyst, which is non-porous and has low specific surface area $\left(<1 \mathrm{~m}^{2} \mathrm{~g}^{-1}\right)$ causes agglomeration and difficulty of filtration for slurry phase operation. While, if sugar catalyst is used in packed bed reactor, it causes the large pressure drop in gas phase reaction due to low void fraction, resulting in both high energy costs and negative consequences on heat and mass transfer. Yet, these limitations can be solved by increasing the surface area per unit volume and particle size of sugar structure through the deposit of powder form of catalyst onto supports which provides an interesting alternative for conventional catalyst in packed beds or slurry reactors [7].

Herein, the coating of a carbon precursor on a structured catalyst supports such as glass, ceramic and aluminium using dip-coating method were studied. Several synthesis conditions have been employed such as hydrothermal carbonization and dry pyrolysis processes with or without pressurized.

\section{Experimental Methods}

\subsection{Materials}

All the materials, D-glucose, glass powder (Si-SC), pocelin (Ceramic, Ce-SC), and Aluminum (Al-SC) powders (0.1 mm diameter) were purchased from SIGMA-ALDRICH, USA and other reagents were: Concentrated sulfuric acid (Fisher Scientific B); Nitrogen gas $\left(\mathrm{N}_{2}\right)$ and Hydrochloric acid (EMSURE Brand, Malaysia); Sodium hydroxide, $\mathrm{NaOH}$ (Nack KGaA, Germany); Barium Chloride, $\mathrm{BaCl}_{2}$ (J.T Baker@ Brand); and phenolphthalein indicator (SIGMA-ALDRICH Brand).

\subsection{Apparatus}

The apparatus used are: Ultrasonic Devices (SONICS Vibracell VCX750); Mass balance (Sartorius-TE2145 and OXFORD PRECISION (OXD-844-2206K); Oven (Memmert); Tube furnace (Enrotherm 2116); Heating mantle (MS- 
E); Magnetic stirrer; Mass Balance; Metal crucible; Two-neck bottom flask; Condenser; Beaker; Thermometer; Conical flask; Filter paper (Whatman $125 \mathrm{~mm}$ ); $\mathrm{pH}$ indicator (Macherey-Nagel); Filter funnel; and Petri dish.

\subsection{Catalyst preparation}

The first step for this stage was preparing the various types of structured surfaces which will act as the catalyst support. Initially, the structured surfaces were prepared by glass rod and ceramic and aluminum by cleaning ultrasonically for 15 minutes and dried in the oven at temperature $100{ }^{\circ} \mathrm{C}$ for 24 hours for removing the surface contaminates which may cause the poor coating result due to impaired coating adhesion.

In the preparation of structured carbon precursor, $d$-glucose was used as the carbon precursor and was converted into carbon char through the carbonization processes which can be carried out through hydrothermal carbonization and dry pyrolysis. Initially, $65 \mathrm{wt} \%$ of $\mathrm{d}$ glucose solution was prepared as the dipcoating solvent by mixing $100 \mathrm{~g}$ of SIGMAALDRICH Brand $d$-glucose with $54 \mathrm{~g}$ of distilled water. The $d$-glucose solution, then, was sonicated by using ultrasonic devices until the $d$-glucose was fully mixed into the solution. Next, the substrates were weighed and dipcoated into the $d$-glucose solution for 1 hour without pressurized. Meanwhile, in order to increase the amount of the carbon char attached on the substrate, pressure vessel was used before carbonization process to increase the adhesive and cohesive strength of carbon precursor with the surface of substrate by pressurizing the samples at $15 \mathrm{~atm}$ for 15 minutes. After the dip-coating process, both pressurized and without pressurized samples were then dried in the oven at $100{ }^{\circ} \mathrm{C}$ for solidifying the glucose layer on the surface substrates [7].

After the structured carbon precursor was prepared, the sample was put into the metal crucible for undergoing dry pyrolysis process. Since the heating only occur in the center of the tube furnace, so the metal crucible must place in the center of tube furnace, otherwise, inefficiency of pyrolysis process will occurs. Then, both end of tube furnace were assembled with the gasket and flanged. The apparatus set up for pyrolysis is shown in the Figure 1.

As shown in Figure 1, one end of the furnace was connected to nitrogen gas while the other end of tube was connected to the beaker containing tap water. Initially, the nitrogen gas, $\mathrm{N}_{2}$ was purge into the tube furnace for 30 minutes with flow rate $100 \mathrm{~mL} / \mathrm{min}$ without turning on the heat of furnace. Then, the heater was turn on and set at $400{ }^{\circ} \mathrm{C}$ for 4 hours pyrolysis (the time taken started when the temperature of furnace reaches $400{ }^{\circ} \mathrm{C}$ ) with continuing purge of $\mathrm{N}_{2}$ gas. After 4 hours pyrolysis, the sample was taking out from furnace and allows to cooling down at room temperature then weighed.

On the other hand, for the hydrothermal carbonization, the preparation for both pressurized and without pressurized samples were same as the procedure above, however, the samples did not undergo the drying process for solidifying the glucose layer on the surface substrates, they were directly undergoing the hydrothermal carbonization process for formation of structured carbon char, while the apparatus set up and operating condition of the hydrothermal carbonization was same with dry pyrolysis process as shown in the Figure 1.

\subsection{Characterization}

The total acidity of the synthesis catalysts

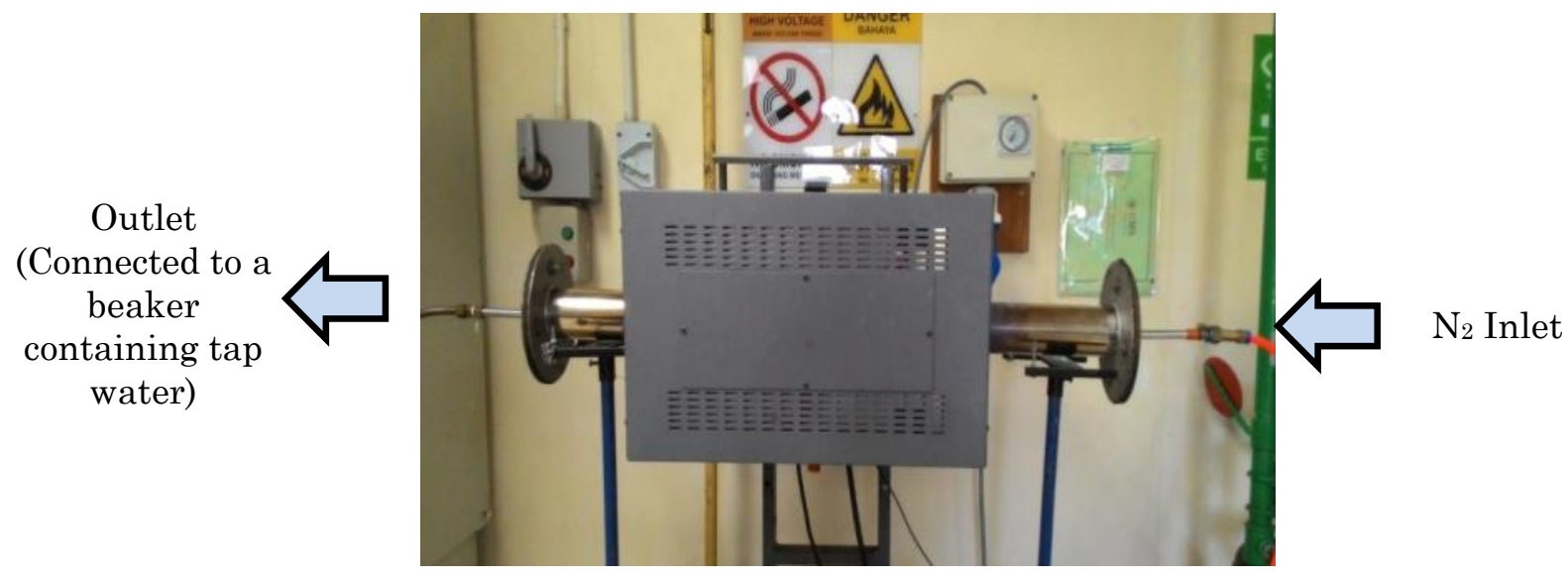

Figure 1. Apparatus set-up for carbonization 
were determined by using acid-base back titration with $0.008 \mathrm{M}$ of $\mathrm{NaOH}$ as titrator and 0.02 $\mathrm{M}$ of $\mathrm{HCl}$ as titrant. The $0.1 \mathrm{~g}$ of the sample is used in a conical flask containing $60 \mathrm{~mL}$ of $0.008 \mathrm{M} \mathrm{NaOH}$. The mixture is stirred for 30 min at room temperature then by using phenolphthalein indicator, and the solution is titrated back with $0.02 \mathrm{M} \mathrm{HCl}$. The final colour light pink indicated the end titration point. The volume of $\mathrm{HCl}$ used in the titration process is recorded. The total acidity was calculated using the following equation:

\section{Total acidity $(\mathrm{mmol} / \mathrm{g})=\left(V_{1} M_{1-}-V_{2} M_{2}\right) 1000 / W$}

where $V_{1}=0.060(\mathrm{~L} \mathrm{NaOH}), V_{2}=$ volume of $\mathrm{HCl}$ used in back titration (L), $M_{1}=$ molarity of $\mathrm{NaOH}$ (gmole/L), $M_{2}=$ molarity of $\mathrm{HCl}$ (gmole/L), $W=$ weight of catalyst (g).

The functional groups of synthesis catalysts were determined by using Fourier Transform Infrared Spectrometry (FTIR, Perkin Elmer, Spectrum 100 series, USA) with the scan range of 650 to $4000 \mathrm{~cm}^{-1}$. The pore size and surface area of catalysts were determined by using Automated Mercury Porosimeter (Pascal 440 series, USA) via mercury intrusion at density temperature of $25^{\circ} \mathrm{C}$ and pressure at $200 \mathrm{MPa}$. Thermal stability of synthesis catalysts was carried out using Thermal Gravimetric Analysis (Perkin Elmer model, TGA6, USA) in the nitrogen atmosphere at the flow rate of 20 $\mathrm{mL} / \mathrm{min}$ and the temperature rate was set at 10 ${ }^{\circ} \mathrm{C} / \min$ to $400{ }^{\circ} \mathrm{C}$.

\section{Results and Discussion}

\subsection{Preparation of structured catalyst}

Table 1 shows that the results of catalyst before coating, after carbonization process and sulfonation process for both dry pyrolysis with and without pressurized and hydrothermal carbonization with and without pressurized. From the results obtained, it can be seen that the chars attached on the catalyst supports were found to be less than $1 \mathrm{~g}$ as the char formation occurs only on the catalyst supports and it is due to less interaction between char molecules and carbon char layer.

\subsection{Total acidity}

Table 2 shows the total acidity of Si-SC, Ce$\mathrm{SC}$, and Al-SC from different preparation methods. The acidity of the synthesis catalysts is contributed by the $-\mathrm{SO}_{3} \mathrm{H}$ group, the phenolic $-\mathrm{OH}$ and $-\mathrm{COOH}$ groups that are contained in the catalyst [9]. Among the catalyst preparation methods, the samples which are prepared from dry pyrolysis without pressurized process showed the strong acidity which is due to the highest adsorption of acid group in the catalyst surface although the catalyst attached onto the support was the least compared to other preparation methods.

Due to porous structure of ceramic surface, it allowed a better interaction between reactants and $-\mathrm{SO}_{3} \mathrm{H}$ sites in the bulk carbon. The ceramic support has highest acidity among the three catalysts samples. However, the acidity of the synthesis catalysts which deposited on glass, ceramic and aluminum supports were lower than the powder form of sugar catalyst which has 2.5 mmol.g-1 total acidity and 1.2 mmol.g- ${ }^{-1}-\mathrm{SO}_{3} \mathrm{H}$ density $[4,6]$. The low acidity of synthesis catalysts may be due to small amount of the carbon attached on the supports during the pyrolysis process as the acidity of the catalyst depends on the amount of surface functional groups $\left(-\mathrm{COOH},-\mathrm{SO}_{3} \mathrm{H}\right.$ and phenolic $-\mathrm{OH}$ group). Besides, the structure of carbon char attached on the surface may not be accessible during sulfonation due to the compact carbon structure on the support, causing low acid density in the final sulfonated catalyst [10].

\subsection{Functional groups}

FT-IR analysis is useful to identify the carbon skeleton structure and groups attached on it. Figure 2 shows the IR spectrum of $\mathrm{Si}-\mathrm{SC}$, Ce-SSC, and Al-SC. Based the results from the Figure 2, several important peaks were

Table 1. Pyrolysis of catalysts

\begin{tabular}{lcccc}
\hline \multirow{3}{*}{ Support } & \multicolumn{2}{c}{$\begin{array}{c}\text { Dry pyrolysis, } \\
\text { Mass of catalyst attached }[\mathrm{g}]\end{array}$} & \multicolumn{2}{c}{$\begin{array}{c}\text { Hydrothermal carbonization, } \\
\text { Mass of catalyst attached }[\mathrm{g}]\end{array}$} \\
\cline { 2 - 5 } & $\begin{array}{c}\text { Without pressurized, } \\
1 \mathrm{~atm}\end{array}$ & $\begin{array}{c}\text { With pressurized, } \\
15 \mathrm{~atm}\end{array}$ & $\begin{array}{c}\text { Without pressur- } \\
\text { ized, 1atm }\end{array}$ & $\begin{array}{c}\text { With pressurized, } \\
15 \mathrm{~atm}\end{array}$ \\
\hline Glass & 0.0092 & 0.0675 & 0.0155 & 0.0036 \\
Ceramic & 0.0018 & 0.0064 & 0.0275 & 0.0059 \\
Aluminum & 0.0081 & 0.0407 & 0.0108 & 0.1734 \\
\hline
\end{tabular}


identified. The FT-IR spectrum of $\mathrm{Si}-\mathrm{SC}, \mathrm{Ce}-$ SC, and Al-SC showed a strong band at $~ 1600$ $\mathrm{cm}^{-1}$ which may be attributed to the polycyclic aromatic framework structure due to $\mathrm{C}=\mathrm{C}$ stretching [3]. The bands at $1040 \mathrm{~cm}^{-1}$ and 1401 $\mathrm{cm}^{-1}$ corresponds to $\mathrm{SO}_{3}$-stretching and $\mathrm{O}=\mathrm{S}=\mathrm{O}$ stretching in $-\mathrm{SO}_{3} \mathrm{H}$, respectively [11]. Furthermore, a broad band was observed at $3400 \mathrm{~cm}^{-1}$ which is assigned to $-\mathrm{OH}$ groups stretching.

The peaks attributable to $\mathrm{O}-\mathrm{H}$ bond in a carboxylic acid group and $\mathrm{O}-\mathrm{H}$ bond in a phenol group can be seen at $3600 \mathrm{~cm}^{-1}$ and 2400 $\mathrm{cm}^{-1}$ [12]. This result provided that the presence of $\mathrm{OH}$ group in the catalyst. In addition, the FT-IR band at $1680 \mathrm{~cm}^{-1}$ shows that the carboxyl acid group presence at the structured sugar catalysts and this band is assigned to $\mathrm{C}=\mathrm{O}$ stretching of $\mathrm{COOH}$ groups [13]. Moreover, peaks attribute to $\mathrm{C}-\mathrm{H}$ and $\mathrm{C}-\mathrm{O}-\mathrm{H}$ asymmetric stretching for all sulfonated char catalysts are observed in the region of 1130-1150 $\mathrm{cm}^{-1}$ [14]. The three structured sugar catalysts in FT-IR spectrums also show that the structured sugar catalyst acid contains resident functionalities including $\mathrm{C}-\mathrm{H}$ at $960 \mathrm{~cm}^{-1}$ and $700 \mathrm{~cm}^{-1}$ which are attributed to trans- $\mathrm{C}-\mathrm{H}$ and cis-C-H out-of-plane bond, respectively [15].
Besides, an aromatic acidic group (Ar-OH stretch) is shown in the IR spectrum at the peak around $1215 \mathrm{~cm}^{-1}$ which is due to oxidation during the carbonization. The presence of a peak at $845 \mathrm{~cm}^{-1}$ is due to noncovalent interaction occurred between the sulfonated pyrene group $\left(-\mathrm{SO}_{3} \mathrm{H}\right)$ and the $\mathrm{Al}-\mathrm{SC}$ at peak $845 \mathrm{~cm}^{-1}$ and is slightly more intense than $\mathrm{Si}-\mathrm{SC}$ and Ce-SC [14].

\subsection{Surface area and porosity}

The characteristics of catalyst were investigated by using mercury intrusion at $25^{\circ} \mathrm{C}$ and $200 \mathrm{MPa}$ (Pascal 440 series,USA). The data of pore diameter, porosity and specific area of the catalyst samples is shown in the Table 3 .

The surface area of sulfonated carbon catalyst in powder form was less than $1 \mathrm{~m}^{2} \mathrm{~g}^{-1}$ $[5,16]$. As shown in Table 3, in this investigation, the surface area of the sulfonated carbon catalysts increased in the range of $1-5 \mathrm{~m}^{2} \mathrm{~g}^{-1}$. The average pore size of the structured sulfonated carbon catalysts were ranging from 116-5768 nm which shows the macroporosity characteristics as the pore diameter is more than $50 \mathrm{~nm}$ [17]. The difference in surface area, pore diameter and porosity of sulfonated

Table 2. Total acidity $[\mathrm{mmol} / \mathrm{g}]$ of catalysts

\begin{tabular}{|c|c|c|c|}
\hline Process & Glass, Si-SC & Ceramic, Ce-SC & Aluminum, Al-SC \\
\hline Dry pyrolysis without pressurized, $1 \mathrm{~atm}$ & 0.917 & 1.327 & 0.321 \\
\hline Dry pyrolysis with pressurized, 15 atm & 0.683 & 0.978 & 0.486 \\
\hline $\begin{array}{l}\text { Hydrothermal Carbonization without Pres- } \\
\text { surized, } 1 \mathrm{~atm}\end{array}$ & 0.641 & 0.684 & 0.401 \\
\hline $\begin{array}{l}\text { Hydrothermal Carbonization with Pressur- } \\
\text { ized, } 15 \mathrm{~atm}\end{array}$ & 0.886 & 1.134 & 0.545 \\
\hline
\end{tabular}

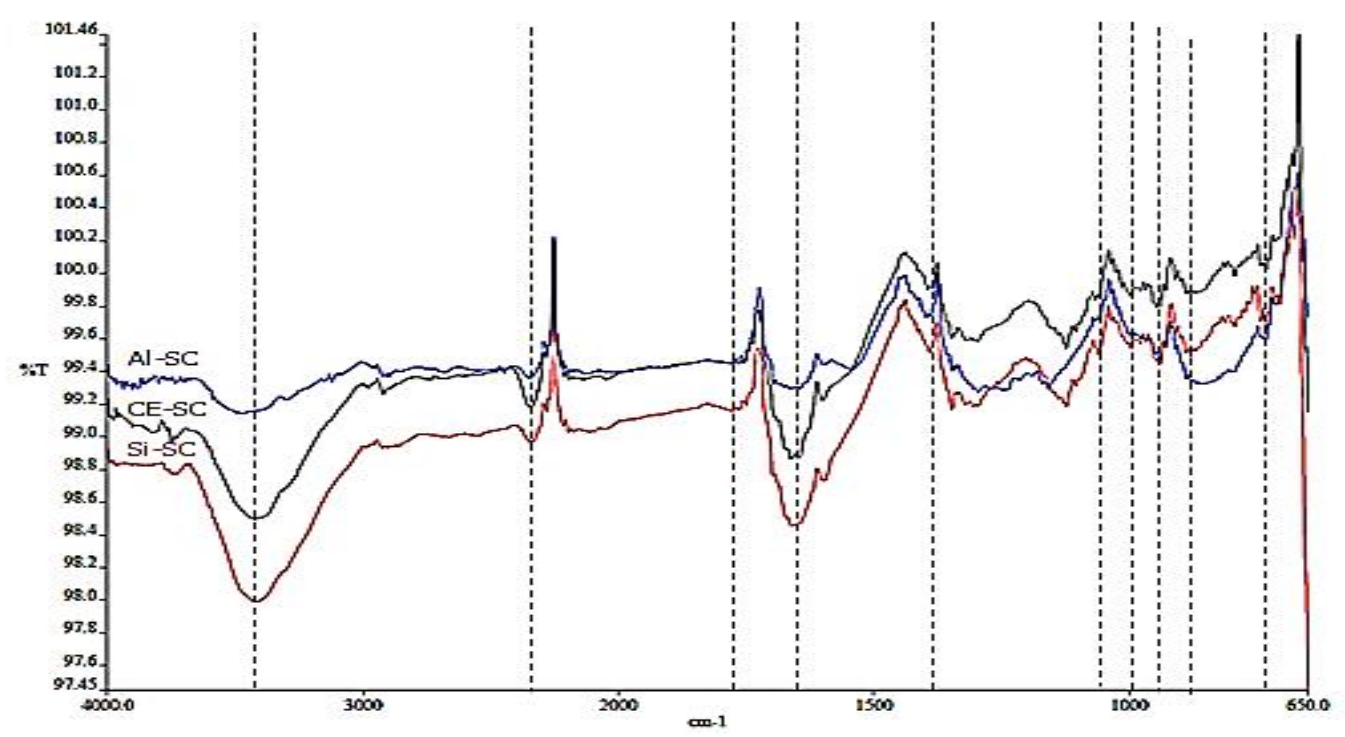

Figure 2. FT-IR spectra of Si-SC, Ce-SC and Al-SC 
carbon catalysts is due to the different surface texture of the catalyst support. Among the synthesis catalysts, the catalyst deposited on the ceramic support $\mathrm{Ce}-\mathrm{SC}$ had the highest surface area because of the three-dimensional cellular structure and porous structure of ceramic material [18]. As shown in Table 3, the glass support had the lowest porosity due to low surface area of catalyst $\mathrm{Si}-\mathrm{SC}$ on non-porous structure of glass surface [19].

\subsection{Composition of elements}

The composition of the carbon-based catalyst on glass, ceramic, and aluminum support was determined by the EDX analysis. From this analysis, the content of $\mathrm{C}, \mathrm{O}$, and $\mathrm{S}$ of $\mathrm{Si}-$ $\mathrm{SC}, \mathrm{Ce}-\mathrm{SC}$, and $\mathrm{Al}-\mathrm{SC}$ was investigated. The surface elemental analysis by EDX technique of $\mathrm{Si}-\mathrm{SC}, \mathrm{Ce}-\mathrm{SC}$, and Al-SC is shown in Table 4.

As shown in Table 4, the sulfur element did not present in all synthesis catalysts. However, from the FT-IR analysis as shown in Figure 2, there were presence of the $-\mathrm{SO}_{3} \mathrm{H}$ groups in the $\mathrm{Si}-\mathrm{SC}, \mathrm{Ce}-\mathrm{SC}$, and $\mathrm{Al}-\mathrm{SC}$ catalysts due to presence of peaks at $1040 \mathrm{~cm}^{-1}$ and $845 \mathrm{~cm}^{-1}$ which represent $\mathrm{SO}_{3}$-stretching and noncovalent interaction between the sulfonated pyrene group $\left(-\mathrm{SO}_{3} \mathrm{H}\right)$. The absence of sulfur element of catalysts in EDX analysis may due to the penetration of sulfonic group into the catalyst support during the sulfonation process. Besides, the composition of the element contained in the catalyst was detected only on the surface of the catalyst by EDX analysis [20].

\subsection{Thermal stability}

The mass change of the catalyst samples as a function of temperature and time in a nitrogen atmosphere is shown in Figure 3. While Figure 4 shows the derivative thermal analysis
(DTA). The temperature was set from 30 to 400 ${ }^{\circ} \mathrm{C}$. Figure 2 and Figure 3 show that there are two distinctive weight losses of the catalyst deposited on the aluminum support Al-SC. The first significant weight loss can be observed at $70{ }^{\circ} \mathrm{C}$. This weight loss of moisture content in the catalyst is due to the temperature which is increased from 25 to $100^{\circ} \mathrm{C}[5,9,17]$. While, the another significant weight loss peak appears at $250{ }^{\circ} \mathrm{C}$ and it is due to the gradual desorption and thermal decomposition process of $\mathrm{Al}-\mathrm{SO}_{3} \mathrm{H}$ group [21,22]. On the other hand, the weight loss of catalyst in glass and ceramic surface is not significant due to high melting point of catalyst supports. Besides, from the TGA analysis as shown in the Figure 3, there are significant temperatures at $100-200^{\circ} \mathrm{C}$ for $\mathrm{Si}-$ $\mathrm{SC}, 50-200{ }^{\circ} \mathrm{C}$ for $\mathrm{Ce}-\mathrm{SC}$, and $30-40^{\circ} \mathrm{C}$ for $\mathrm{Al}-$ $\mathrm{SC}$. The weight gain at the respective temperature range is due to the absorption of nitrogen gas or reaction with gaseous substances in the purged gas. From the TGA analysis, the final weight $\%$ for $\mathrm{Si}-\mathrm{SC}, \mathrm{Ce}-\mathrm{SC}$, and $\mathrm{Al}-\mathrm{SC}$ were $99.8 \%, 99.9 \%$, and $98.8 \%$ respectively. Thus, the catalysts which deposited on the support are stable as there is only slight decrease in weight loss \% compared to powder form of sugar catalyst which was $84.0 \%$ within the $400{ }^{\circ} \mathrm{C}[16]$.

\section{Conclusions}

In this research, three catalyst $\mathrm{Si}-\mathrm{SC}, \mathrm{Ce}-$ $\mathrm{Sc}$, and Al-SC supports were used to prepare amorphous sulfonated carbon-base catalysts. Among the catalysts, the sulfonated carbonbase catalyst that is attached on the ceramic support had the highest acidity (1.327 $\mathrm{mmol} / \mathrm{g}$ ), followed by the catalyst deposited on the glass $(0.917 \mathrm{mmol} / \mathrm{g})$ and aluminum $(0.321$ $\mathrm{mmol} / \mathrm{g})$ supports. The porous structure of ce-

Table 3. Surface area, pore diameter and porosity of synthesis catalysts

\begin{tabular}{lccc}
\hline \multicolumn{1}{c}{ Catalyst } & Surface Area $\left[\mathrm{m}^{2} / \mathrm{g}\right]$ & Pore Diameter $[\mathrm{nm}]$ & Porosity [\%] \\
\hline Glass, Si-SC & 1.02 & 116.79 & 0.33 \\
Ceramic, Ce-SC & 4.56 & 112.50 & 1.94 \\
Aluminum, Al-SC & 3.56 & 5768.46 & 1.97 \\
\hline
\end{tabular}

Table 4. Surface elemental analysis by EDX technique of the Si-SC, Ce-SC, and Al-SC catalysts

\begin{tabular}{ccccccccc}
\hline \multirow{2}{*}{ Catalyst } & \multicolumn{3}{c}{ Elements [wt.\%] } & \multicolumn{3}{c}{ Elemental analysis by EDX [mol] } & \multicolumn{2}{c}{ Mole Ratio to Carbon } \\
\cline { 2 - 8 } & $\mathrm{C}$ & $\mathrm{O}$ & $\mathrm{S}$ & $\mathrm{C}$ & $\mathrm{O}$ & $\mathrm{S}$ & O:C & S:C \\
\hline Si-SC & 83.35 & 12.53 & - & 6.95 & 0.78 & - & 0.11 & - \\
Ce-SC & 60.73 & 34.26 & - & 5.06 & 2.14 & - & 0.42 & - \\
Al-SC & 81.56 & 17.54 & - & 6.80 & 1.10 & - & 0.16 & - \\
\hline
\end{tabular}


ramic surface allowed a better interaction between reactants and $-\mathrm{SO}_{3} \mathrm{H}$ site in the carbon. From the FT-IR analysis, it was observed that the functional groups $-\mathrm{COOH},-\mathrm{OH}$, and $-\mathrm{SO}_{3} \mathrm{H}$ were present in the active sites of the catalysts. The surface areas of the catalysts $\mathrm{Si}-\mathrm{SC}, \mathrm{Ce}-\mathrm{SC}$ and $\mathrm{Al}-\mathrm{SC}$ were larger than 1 $\mathrm{m}^{2} / \mathrm{g}$, whereas the pore size belongs to macroporous as the average pore size is more than 50 $\mathrm{nm}$. It is stable within the temperature of 400 ${ }^{\circ} \mathrm{C}$ as there was less than $10 \%$ weight loss through the TGA analysis.

\section{References}

[1] Chen, W.H., Chen, C.J., Hung, C.I., Shen, C.H., Hsu, H.W. (2013). A Comparison of Gasification Phenomena among Raw Biomass, Torrefied Biomass and Coal in an Entrained-flow Reactor. Applied Energy, 112: 421-430.

[2] West, A.H., Posarac, D., Ellis, N. (2008). Assessment of Four Biodiesel Production Processes using HYSYS Plant. Bioresource Technology, 99: 6587-6601.

[3] Janaun, J., Ellis, N. (2010). Perspectives on Biodiesel as a Sustainable Fuel. Renewable Sustainable Energy Reviews, 14: 1312-1320.

[4] Cho, H.J., Kim, S.H., Hong, S.W., Yeo, Y.K. (2012). A Single Step Non-catalytic Esterification of Palm Fatty Acid Distillate (PFAD) for Biodiesel Production. Fuel, 93: 373-380.

[5] Mo, X., Lotero, E., Lu, C., Liu, Y., James, G.G.J. (2008). A Novel Sulfonated Carbon Composite Solid Acid Catalyst for Biodiesel Synthesis. Catalysis Letters, 123: 1-6.

[6] Suganuma, S., Nakajima, K., Kitano, M., Kato, H., Tamura, A., Kondo, H., Yanagawa, S., Hayashi, S., Hara, M. (2011). $\mathrm{SO}_{3} \mathrm{H}-$ bearing Mesoporous Carbon with Highly Selective Catalysis. Microporous and Mesoporous Materials, 143: 443-450.

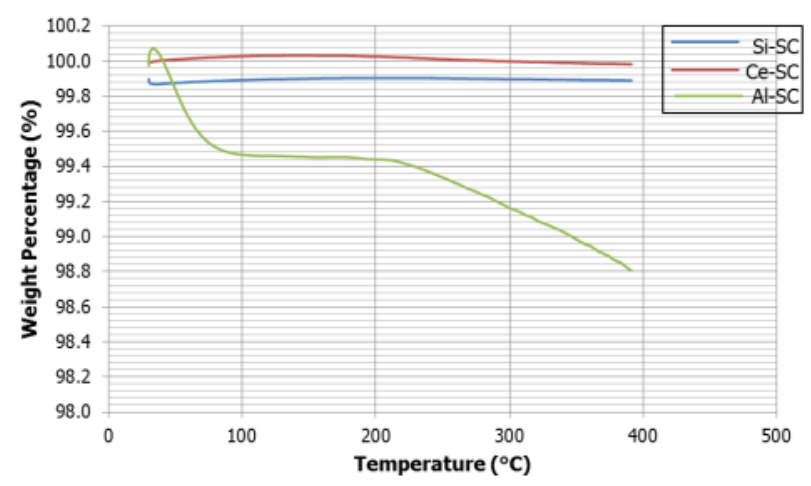

Figure 3. Thermo-gravimetric analyses of $\mathrm{Si}-$ $\mathrm{SC}, \mathrm{Ce}-\mathrm{SC}$, and $\mathrm{Al}-\mathrm{SC}$ under nitrogen.
[7] Hosseini, S., Janaun, J., Choong, T.S.Y. (2015). Sulfuric Acid Functionalized Carbon Coated Honeycomb Monolith as Solid Acid Catalyst for Synthesis of Methyl Esters from Palm Fatty Acid Distillate (PFAD). Process Safety and Environmental Protection, 98: 285-295.

[8] Janaun, J., Ellis, N. (2010). Role of Silica Template in the Preparation of Sulfonated Mesoporous Carbon Catalysts. Applied Catalysis A: General, 394: 25-31.

[9] Liu, X.Y., Huang, M., Ma, H.L., Zhan, Z.Q., Gao, J.M., Zhu, Y.L., Guo, X.F. (2010). Preparation of a Carbon-based Solid Acid Catalyst by Sulfonating Activated Carbon in a Chemical Reduction, Process Molecules, 15: 71887196.

[10] Konwar, L.J., Boro, J., Deka, D. (2014). Review on Latest Developments in Biodiesel Production using Carbon-based Catalysts. Renewable Sustainable Energy Reviews, 29: 546 564 .

[11] Lu, Y., Liang, X., Qi, C. (2012). Synthesis of Novel Carbon/Silica Composites based Strong Acid Catalyst and its Catalytic Activities for Acetalization. Bulletin of Materials Science, 35: 419-424.

[12] Fu, Z., Wan, H., Hu, X., Cui, Q., Guan, G. (2012). Preparation and Catalytic Performance of a Carbon-based Solid Acid Catalyst with High Specific Surface Area. Reaction Kinetics Mechanism and Catalysis, 107: 203213.

[13] Liang, F., Song, Y., Huang, C., Zhang, J., Chen, B. (2013). Preparation and Performance Evaluation of a Lignin-based Solid Acid from Acid Hydrolysis Lignin. Catalysis Communications, 40: 93-97.

[14] Liu, X.Y., Huang, M., Ma, H.L., Zhang, Z.Q., Gao, J.M., Zhu, Y.L., Han, X.J., Guo, X.Y. (2010). Preparation of a Carbon-Based Solid Acid Catalyst by Sulfonating Activated Carbon in a Chemical Reduction Process, Molecules, 15: 7188-7196.

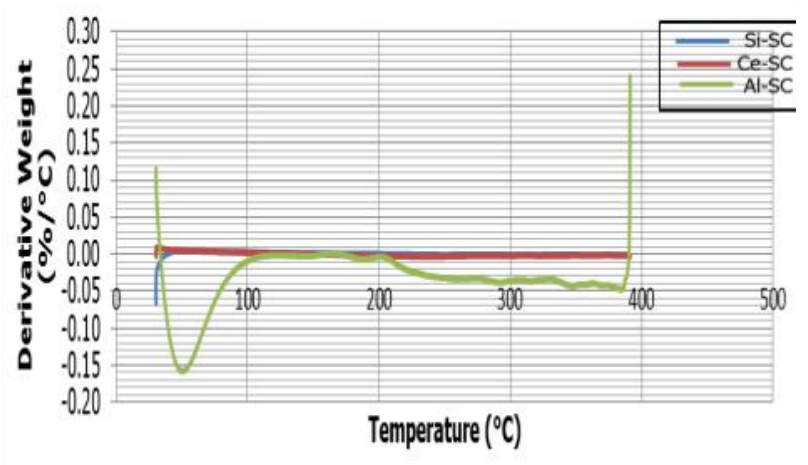

Figure 4. Derivative thermal analyses of Si$\mathrm{SC}, \mathrm{Ce}-\mathrm{SC}$, and $\mathrm{Al}-\mathrm{SC}$ under nitrogen. 
[15] Meyers. R.A. ed. (2000). Interpretation of Infrared Spectra, A Practical Approach. Encyclopedia of Analytical Chemistry. John Wiley \& Sons Ltd, Chichester.

[16] Janaun, J. (2012). Development of Sulfonated Carbon Catalysts for Integrated Biodiesel Production. Ph.D Dissertation, University of British Columbia, Canada.

[17] Hayes, R., Kolaczkowsk, S.T. (1998). Introduction to Catalytic Combustion. CRC Press, UK.

[18] Carty, W.M., Lednor, P.W. (1996). Monolithic Ceramics and Heterogeneous Catalysts: Honeycombs and Foams, Current Opinion in Solid State \& Material Science, 1: 88-95.

[19] Janaun, J., Ellis, N. (2010). Glycerol Etherification by tert-Butanol Catalyzed by Sulfonated Carbon Catalyst. Journal of Applied Sciences, 10: 2633-2637.
[20] Pua, F., Fang, Z., Zakaria, S., Guo, F., Chia, C. (2011). Direct Production of Biodiesel from High-acid Value Jatropha Oil with Solid Acid Catalyst Derived from Lignin. Biotechnology Biofuels, 4: 56 (doi: 10.1186/1754-6834-4-56)

[21] Lee, D., (2013). Preparation of a Sulfonated Carbonaceous Material from Lignosulfonate and Its Usefulness as an Esterification, $\mathrm{Ca}$ talysis Molecules, 10: 8168-8180.

[22] Thermogravimetric Analysis (TGA) / Differential Thermal Analysis (DTA) Testing \& Analytical Services. (2015) http://www.eag.com/mc/thermogravimetricdifferential-thermal-analysis.html 